\title{
Phytochemical analysis and antioxidant activity essential oil of anaphalis contorta from uttrakhand himalayas
}

\begin{abstract}
Background: Anaphalis contorta shows antiasthmatic, anticoughing, expectorant and antiphlogistic activity. The leaves of Anaphalis Controta were collected in the month of Spetmber 2015 from Kosi Katarmal near Almora, location of Kumaun Himalayas.

Methods: The plant Anaphalis contorta including leaves, stem flower, were extracted by hydro distillation method for 6 hours using Clevenger apparatus The hydro-distilled essential oil of Anaphalis contorta has been examined by means of gas chromatographymass spectrometry (GC-MS). Take $1.0 \mathrm{ml} \mathrm{E}$. Oil of various code samples and mixed with in 4.0ml DMSO (Dimethyl sulfoxide). The prepared extract was used for the determination of antioxidant activity (i.e., DPPH assay \& ABTS assay) in among samples.

Results: Fifty-two constituents have been identified representing $89.64 \%$ of the total oil. The major constituents were E-caryophyllene (16.33\%), $\beta$-himachalene $(9.15 \%), \delta$-cadinene $(9.07 \%), \alpha$-pinene $(5.58 \%)$. The oil was rich in sesquiterpene hydrocarbon $(53.71 \%)$, followed by oxygenated sesquiterpene (21.49\%), Among sesquiterpene hydrocarbons, made its significant percentage.
\end{abstract}

Conclusion: The results data obtained in the present study suggest that some essential oils possess strong medicinal activities, which can be utilized for treatment of certain diseases.

Keywords: (E)-caryophyllene, anaphalis controta, essential oil, GC-MS, antioxidant activity
Volume 6 Issue 2 - 2017

Kavita Rawat, Kundan Prasad, Ganga Bisht

Department of Chemistry, DSB Campus, KU Nainital, India

Correspondence: Kundan Prasad, Department of Chemistry, DSB Campus, KU Nainital, Uttrakhand, India, Tel 9.1969 IE+ I I, Email gicgarkha@gmail.com

Received:September 10, 2017 | Published: September 25, 2017
Abbreviations: DMSO, dimethylsulfoxide; DPPH, 2,2-diphenyl-1-picrylhydrazyl; GC-MS, gas chromatography/ mass spectrometry; GC-FID, gas chromatography/flame ionization detector; RI, retention index

\section{Introduction}

Anaphalis contortaHook is an erect herb. The stem is branched from the base,branches are often decumbent. The leaves are linear, crowded, shortly lobed at the base, margins recurved sometimes. The heads are in dense terminal corymbs and in involucral bracts are broad, obtuse, erect in flower, spreading in fruit; outer ones often pale purple. A. contorta is widely distributed in temperate region from Kashmir to Sikkim and Afghanistan to South West China at a height of $1500-4500 \mathrm{~m}^{1-3}$

Anaphalisis a genus of flowering plants within the Asteraceae family, whose membersare commonly known by the name pearl or pearly everlasting. Anaphalis is the largest genus within the Asian Gnaphalieae and it is well diversified in the Himalayas and the Qinghai-Tibet Plateauregion. ${ }^{4}$ It comprises approximately 110 species, mostly distributed in Asia. Various medicinal plants have been used for years in day to day life to treat diseases all over the world. The use of traditional medicine and medicinal plants in developing countries, to meet some of their primary health care needs, has been widely documented. The family Asteraceae is one of the largest plant families on which the wound healing activity studies have been focused. The fresh leaves of this plant and some other Anaphalis species are bruised and applied to the cut wounds under a rag bandage. ${ }^{5}$ When taken before meals, the leaves stimulate the appetite and as a result, it is administered to convalescents for its sedative and tonic properties. It shows antiasthmatic, anticoughing, expectorant and antiphlogistic activity. The oil of Anaphalis contorta has been found to possess antibacterial and antifungal activity. ${ }^{7}$ Present investigation of arial parts of the plant (leaves, pre-mature and mature seeds and fruits) were taken to isolate essential oils and aim of the present study was to analyze the composition of the oils of $A$. contorta and antioxidant properties.

\section{Materials and methods}

\section{Plant material}

The leaves of Anaphalis Controta were collected in the month of Spetmber 2015 from Kosi Katarmal near Almora, location of Kumaun Himalayas, The plant was authenticated by Botanical Survey of India (BSI).

\section{Isolation of essential oil}

The plant Anaphalis contorta including leaves, stem flower, were extracted by hydro distillation method for 6 hours using Clevenger apparatus. ${ }^{8}$ The oil was dried with anhydrous sodium Sulphate and stored at room temprature in a sealed vial until analysis was performed. The percentage oil yield was calculated based on the dry weight of the leaf. The oil yield was $(0.7 \%)$.

\section{GC-FID and GC-MS analysis}

Essential oil analysis was performed by using GC-MS and GC-FID was performed on a Shimadzu QP-2010 instrument, equipped with FID, in the same conditions, except hydrogen was used as the carrier gas. The percentage composition of the oil samples were computed from the GC peak areas without using correction for response factors. The oils were analyzed using a Shimadzu GC/MS Model QP 2010 Plus, equipped with a Rtx-5MS $(30 \mathrm{~m} \times 0.25 \mathrm{~mm} ; 0.25 \mathrm{~mm}$ film 
thickness) fused silica capillary column. Helium was used as carrier gas adjusted to $1.21 \mathrm{ml} / \mathrm{min}$ at $69.0 \mathrm{KPa}$; splitless injection of $1 \mathrm{~mL}$, of a hexane solution; injector and interface temperature were $270^{\circ} \mathrm{C}$; oven temperature programmed was $50-280^{\circ} \mathrm{C}$ at $3 \mathrm{C} / \mathrm{min}$. EIMS: electron energy, $70 \mathrm{eV}$; ion source temperature was $230^{\circ} \mathrm{C}$.

Identification of constituents were done on the basis of Retention Index (RI, determined with reference to homologous series of n-alkanes C8-C28, under identical experimental condition), MS library search (NIST and WILEY), and by comparison with MS literature data. ${ }^{9}$ The relative amounts of individual components were calculated based on GC peak area (FID response) without using correction factor. Retention indices (RI) were determined with reference to a homologous series of normal Alkanes.

\section{Extract preparation for antioxidant analysis}

Take $1.0 \mathrm{ml} \mathrm{E}$. Oil of various code samples and mixed with in 4.0ml DMSO (Dimethyl sulfoxide). The prepared extract was used for the determination of antioxidant activity (i.e., DPPH assay \& ABTS assay) in among samples.

\section{Chemicals and reagents}

1,1-Diphenyl-2-picrylhydrazyl (DPPH) radical, gallic acid, ascorbic acid, chlorogenic acid, caffeic acid, $\rho$-coumaric acid, 3-hydroxybenzoic acid, catechin and quercetin were procured from Sigma-Aldrich (Steinheim, Germany). Sodium carbonate, 2-(n-morpholino) ethanesulfonic acid (MES buffer), potassium persulphate, ferric chloride, sodium acetate, potassium acetate, aluminium chloride, glacial acetic acid and hydrochloric acid from Qualigens (Mumbai, India), and 2,2_-azinobis(3-ethylbenzothiazoline6-sulphonic acid) (ABTS), 2,4,6-tri-2-pyridyl-1,3,5-triazin (TPTZ), methanol and ethanol from Merck Company (Darmstadt, Germany).

\section{diphenyl-I-picrylhydrazyl (DPPH) assay}

Free radical DPPH scavenging assay was slightly modified [10] for the present study. DPPH $(100 \mu \mathrm{M})$ was prepared in $80 \%(\mathrm{w} / \mathrm{v})$ ethanol and $2.7 \mathrm{ml}$ mixed with $0.9 \mathrm{ml}$ of sample extract and allowed to stand in the dark $(22 \pm 10 \mathrm{C}, 20 \mathrm{~min})$. The reduction in the absorbance at $520 \mathrm{~nm}$ was recorded and results expressed in $\mathrm{mM}$ ascorbic acid equivalent per $100 \mathrm{~g}(\mathrm{mM} \mathrm{AAE} / 100 \mathrm{~g})$.

\section{Azinobis ( 3 benzylthiazole)-6- sulphonic acid (ABTS) assay}

Total antioxidant activity was measured by improved ABTS (ethylbenzothiazoline 6-sulphonic acid) radical scavenging method. ${ }^{11,12}$ In brief, ABTS $(7.0 \mu \mathrm{M})$ and potassium persulphate $(2.45 \mu \mathrm{M})$ were added in amber coloured bottle for the production of ABTS cation $\left(\mathrm{ABTS}^{\circ}+\right)$ and kept in the dark $\left(16 \mathrm{~h}, 22 \pm 1^{\circ} \mathrm{C}\right)$. $\mathrm{ABTS}^{\circ}+$ solution was diluted with $80 \%(\mathrm{v} / \mathrm{v})$ ethanol till an absorbance of $0.700 \pm 0.05$ at $734 \mathrm{~nm}$ is obtained. For sample analysis, $3.90 \mathrm{ml}$ of diluted $\mathrm{ABTS}^{*}+$ solution was added to $0.10 \mathrm{ml}$ of methanolic extract and mixed thoroughly. The reaction mixture was allowed to stand $(22 \pm 1 \mathrm{oC}, 6 \mathrm{~min}$, dark) and the absorbance was recorded at $734 \mathrm{~nm}$ with respect to blank. A standard curve of various concentrations of ascorbic acid is prepared in $80 \% \mathrm{v} / \mathrm{v}$ methanol for the equivalent quantification of antioxidant potential with respect to ascorbic acid. Results were expressed in $\mathrm{mM}$ ascorbic acid equivalent per $100 \mathrm{~g}(\mathrm{mM}$ AAE /100g).

\section{Results and discussion}

\section{Essential oil composition}

The GC and GC-MS analysis of Anaphalis contorta resulted in the identification of fifty-two constituents, the oil yield was found to be $0.7 \%$ by weight. Both, the major as well as minor constituents were identified by their retention indices and comparison of their mass spectra. Total fifty-seven constituents were identified constituting $89.64 \%$ of the total oil. The main compounds in major amounts were E-caryophyllene $(16.33 \%), \quad \beta$-Himachalene $(9.15 \%), \delta$-cadinene $(9.07 \%), \alpha$-pinene $(5.58 \%)$. The oil was rich in sesquiterpene hydrocarbon $(53.71 \%)$, followed by oxygenated sesquiterpene (21.49\%), Among sesquiterpene hydrocarbons, made its significant percentage. This is the first report on the composition of essential oil from Anaphalis contorta Table (1\&2).

Table I Essential oil composition of the Anaphalis contorta

\begin{tabular}{|c|c|c|c|c|c|c|}
\hline S.N. & Compound & Area \% & Mol. Formula & Mol.Wt. & $\mathbf{R I}$ & Mode of Identification \\
\hline I & 4,5-Dimethyl-4-hexen-3-one & 0.12 & $\mathrm{C}_{8} \mathrm{H}_{14} \mathrm{O}$ & 126 & 915 & $a, b$ \\
\hline 2 & $\alpha$-Pinene & 5.58 & $\mathrm{C}_{10} \mathrm{H}_{16}$ & 136 & 933 & $a, b$ \\
\hline 3 & $\beta$-Pinene & 0.08 & $\mathrm{C}_{10} \mathrm{H}_{16}$ & 136 & 978 & $a, b$ \\
\hline 4 & Myrcene & 0.12 & $\mathrm{C}_{10} \mathrm{H}_{16}$ & 136 & 987 & $a, b$ \\
\hline 5 & (4E)-4-Hexenyl acetate & 0.12 & $\mathrm{C}_{8} \mathrm{H}_{14} \mathrm{O}_{2}$ & 142 & 992 & $a, b$ \\
\hline 6 & Limonene & 0.2 & $\mathrm{C}_{10} \mathrm{H}_{16}$ & 136 & 1024 & $a, b$ \\
\hline 7 & Ocimene & 0.14 & $\mathrm{C}_{10} \mathrm{H}_{16}$ & 136 & 1029 & $a, b$ \\
\hline 8 & (E)- $\beta$-ocimene & 0.43 & $\mathrm{C}_{10} \mathrm{H}_{16}$ & 136 & 1046 & $a, b$ \\
\hline 9 & Linalool & 0.29 & $\mathrm{C}_{10} \mathrm{H}_{18} \mathrm{O}$ & 154 & 1101 & $a, b$ \\
\hline 10 & Lavandulol & 0.22 & $\mathrm{C}_{10} \mathrm{H}_{18} \mathrm{O}$ & 154 & 1150 & $a, b$ \\
\hline II & Safranal & 0.15 & & 150 & 1182 & $a, b$ \\
\hline 12 & Lavandulyl acetate & 1.12 & $\stackrel{10}{C}_{12} \stackrel{H}{H}_{20} \mathrm{O}_{2}$ & 196 & 1275 & $a, b$ \\
\hline 13 & $\alpha$-Cubebene & 0.33 & $\mathrm{C}_{15} \mathrm{H}_{24}$ & 204 & 1349 & $a, b$ \\
\hline 14 & $\alpha$ - Copaene & 1.3 & $\mathrm{C}_{15} \mathrm{H}_{24}$ & 204 & 1375 & $a, b$ \\
\hline 15 & $\alpha$-ylangene & 0.9 & $\mathrm{C}_{15} \mathrm{H}_{24}$ & 204 & 1376 & $a, b$ \\
\hline 16 & Italicene & I.II & $\mathrm{C}_{15} \mathrm{H}_{24}$ & 204 & 1408 & $a, b$ \\
\hline 17 & E- Caryophyllene & 16.33 & $\mathrm{C}_{15} \mathrm{H}_{24}$ & 204 & 1419 & $a, b$ \\
\hline 18 & $\alpha$ - Humulen & 1.12 & $\mathrm{C}_{15} \mathrm{H}_{24}$ & 204 & 1454 & $a, b$ \\
\hline 19 & Sesquisabinene & 0.14 & $\mathrm{C}_{15} \mathrm{H}_{24}$ & 204 & 1455 & $a, b$ \\
\hline 20 & 9-epi-(E)- $\beta$-Caryophyllene & 0.68 & $\mathrm{C}_{15} \mathrm{H}_{24}$ & 204 & 1464 & $a, b$ \\
\hline
\end{tabular}




\begin{tabular}{|c|c|c|c|c|c|c|}
\hline S.N. & Compound & Area \% & Mol. Formula & Mol.Wt. & $\mathbf{R I}$ & Mode of Identification \\
\hline 21 & Cadina-I (6),4-diene & 0.68 & $\mathrm{C}_{15} \mathrm{H}_{24}$ & 204 & 1472 & $\mathrm{a}, \mathrm{b}$ \\
\hline 22 & Germacrene-D & 0.24 & $\mathrm{C}_{15} \mathrm{H}_{24}$ & 204 & 1475 & $a, b$ \\
\hline 23 & trans- $\beta$-Bergamotene & 3.18 & $\mathrm{C}_{15} \mathrm{H}_{24}$ & 204 & 1480 & $a, b$ \\
\hline 24 & trans-b-Bergamotene & 0.65 & $\mathrm{C}_{15} \mathrm{H}_{24}$ & 204 & 1483 & $a, b$ \\
\hline 25 & Viridiflorene & 1.88 & $\mathrm{C}_{15} \mathrm{H}_{24}$ & 204 & |49| & $a, b$ \\
\hline 26 & $\beta$-Himachalene & 9.15 & $\mathrm{C}_{15} \mathrm{H}_{24}$ & 204 & 1503 & $a, b$ \\
\hline 27 & $\gamma$-Cadinene & 2.37 & $\mathrm{C}_{15} \mathrm{H}_{24}$ & 204 & 1507 & $a, b$ \\
\hline 28 & Cubebol & 0.87 & $\mathrm{C}_{15} \mathrm{H}_{26} \mathrm{O}$ & 222 & 1514 & $\mathrm{a}, \mathrm{b}$ \\
\hline 29 & $\delta$-cadinene & 9.07 & $\mathrm{C}_{15} \mathrm{H}_{24}$ & 204 & 1520 & $a, b$ \\
\hline 30 & $\alpha$-curcumene & 0.65 & $\mathrm{C}_{15} \mathrm{H} 22$ & 202 & 1536 & $a, b$ \\
\hline 31 & $\alpha$ - Cadinene & 2.46 & $\mathrm{C}_{15} \mathrm{H}_{24}$ & 204 & 1538 & $a, b$ \\
\hline 32 & $\beta$ - Bulnesene & 1.45 & $\mathrm{C}_{15} \mathrm{H}_{24}$ & 204 & 1558 & $a, b$ \\
\hline 33 & $\beta$-Calacorene & 0.26 & $\mathrm{C}_{15} \mathrm{H}_{20}$ & 200 & 1564 & $a, b$ \\
\hline 34 & Isoshyobunone & 0.15 & $\mathrm{C}_{15} \mathrm{H}_{24} \mathrm{O}$ & 220 & |57| & $a, b$ \\
\hline 35 & Axenol & 0.58 & $\mathrm{C}_{15} \mathrm{H}_{26} \mathrm{O}$ & 222 & 1574 & $a, b$ \\
\hline 36 & Globulol & 0.69 & $\mathrm{C}_{15} \mathrm{H}_{26} \mathrm{O}$ & 222 & 1586 & $a, b$ \\
\hline 37 & Caryophyllene oxide & 2.38 & $\mathrm{C}_{15} \mathrm{H}_{24} \mathrm{O}$ & 220 & 1587 & $\mathrm{a}, \mathrm{b}$ \\
\hline 38 & Copaborneol & 0.44 & $\mathrm{C}_{15} \mathrm{H}_{26} \mathrm{O}$ & 222 & 1613 & $a, b$ \\
\hline 39 & I,I0- Diepicubenol & 0.58 & $\mathrm{C}_{15} \mathrm{H}_{26} \mathrm{O}$ & 222 & 1618 & $a, b$ \\
\hline 40 & Epicubenol & 2.02 & $\mathrm{C}_{15} \mathrm{H}_{26} \mathrm{O}$ & 222 & 1631 & $a, b$ \\
\hline 41 & Epi- $\alpha$-Cadinol & 3.72 & $\mathrm{C}_{15} \mathrm{H}_{26} \mathrm{O}$ & 222 & 1640 & $\mathrm{a}, \mathrm{b}$ \\
\hline 42 & Pogostol & 4.98 & $\mathrm{C}_{15} \mathrm{H}_{26} \mathrm{O}$ & 222 & 1650 & $\mathrm{a}, \mathrm{b}$ \\
\hline 43 & Epi- $\beta$-Bisabolol & 2.66 & $\mathrm{C}_{15} \mathrm{H}_{26} \mathrm{O}$ & 222 & 1675 & $\mathrm{a}, \mathrm{b}$ \\
\hline 44 & $\alpha$-Bisabolol & 0.83 & $\mathrm{C}_{15} \mathrm{H}_{26} \mathrm{O}$ & 222 & 1688 & $\mathrm{a}, \mathrm{b}$ \\
\hline 45 & Murolan-3,9(I I)-diene-10-peroxy & 0.24 & $\mathrm{C}_{15} \mathrm{H}_{24} \mathrm{O}_{2}$ & 236 & 1729 & $\mathrm{a}, \mathrm{b}$ \\
\hline 46 & Cembrene & 0.59 & $\mathrm{C}_{20} \mathrm{H}_{32}$ & 272 & 1939 & $\mathrm{a}, \mathrm{b}$ \\
\hline 47 & Sclarene & 0.33 & $\mathrm{C}_{20} \mathrm{H}_{32}$ & 272 & 1943 & $a, b$ \\
\hline 48 & m-Camphorene & 0.34 & $\mathrm{C}_{20} \mathrm{H}_{32}$ & 272 & 1946 & $a, b$ \\
\hline 49 & Neocembrene & 0.7 & $\mathrm{C}_{20} \mathrm{H}_{32}$ & 272 & 1960 & $a, b$ \\
\hline 50 & n-Hexadecanoic acid & 0.2 & $\mathrm{Cl}_{6} \mathrm{H}_{32} \mathrm{O}_{2}$ & 256 & 1977 & $a, b$ \\
\hline 51 & Manool & 3.37 & $\mathrm{C}_{20} \mathrm{H}_{34} \mathrm{O}$ & 290 & 2062 & $a, b$ \\
\hline \multirow[t]{2}{*}{52} & Labd-7,| 3-dien-I5-ol & 1.45 & $\mathrm{C}_{20} \mathrm{H}_{34} \mathrm{O}$ & 290 & 2293 & $a, b$ \\
\hline & & 89.64 & & & & \\
\hline
\end{tabular}

$a=$ Retention Index (RI); b=MS (GC-MS).

Table 2 Essential oil of Anaphalis contorta, contain the following classes of chemical compounds

\begin{tabular}{lll}
\hline SN & Chemical Composition & Percentage \\
\hline 1 & Monoterpene hydrocarbon & $6.55 \%$ \\
2 & Oxygenated monoterpene & $0.90 \%$ \\
3 & Sesqueterpene hydrocarbon & $53.71 \%$ \\
4 & Oxygenated sesquiterepene & $21.49 \%$ \\
5 & Diterepene hydrocarbon & $1.8 \%$ \\
6 & Oxygenated diterepene & $4.82 \%$ \\
\hline
\end{tabular}

Table 3 Antioxidant activity (DPPH \& ABTS assay) in Anaphalis contorta

\begin{tabular}{lll}
\hline Name of Plants & DPPH Activity (mMAAE/I00g) & DPPH Activity (mMAAE/I00g) \\
Anaphalis contorta & $9.47 \pm 0.03$ & $7.31 \pm 0.01$
\end{tabular}

\section{Antioxidant activity}

The essential oil showed good DPPH and ABTS radical scavenging activity. Antioxidant activity of plants $A$. contorta analyzed (Table 3). The free radical scavenging activity (DPPH assay) was $9.47 \mathrm{mM}$ AAE $/ 100 \mathrm{~g}$ recorded in Anaphalis contortaaromatic oil. Total antioxidant activity (ABTS assay) was found (7.31mMAAE/100g) in A. contorta aromatic oil. This activity is significant, especially since this essential oil are composed mainly of monoterpenes and sesquiterpene hydrocarbons and oxygenated ones which have a moderate activity compared to phenolics and vitamin C. Our findings revealed that the percentage of oxygenated monoterpenes was $0.90 \%$ and monoterpenes hydrocarbons was $6.55 \%$. This result might be related to the antioxidant activity of our essential oil. All the essential oils had low amounts of phenolic compounds but showed good antioxidant activity. The diversified mono- and sesquiterpenoids present in the complex mixture of essential oils might be responsible for the good antioxidant activity because of synergetic effects of the constituents. This can be evidenced by a report which says that antioxidant capacity is affected by other bioactive compounds and could involve synergistic effects. ${ }^{13}$ 


\section{Conclusion}

The essential oil from Anaphalis contorta showed a qualitative and quantitative make-up of constituents. The oils also showed good antioxidant activities. Clinically, this herb can be a good source of herbal medicine for the treatment of diseases indigenously. The study will also help to generate a database of species which can be exploited scientifically and judiciously in the future by local people and so that ecological balance is maintained. The results data obtained in the present study suggest that some essential oils possess strong medicinal activities, which can be utilized for treatment of certain diseases.

\section{Acknowledgements}

The authors are grateful to AIRF, Jawaharlal Nehru University, New Delhi for the Gas Chromatography coupled with Mass Spectrometry (GC-MS), and Gas Chromatography with flame ionization detection (GC-FID) analysis facilities \& Botanical Survey of India, for the identification of plant specimen. The authors are grateful to Dr. I. D. Bhatt Scientist-D, G.B.P.N.I.H.E.S.D., Kosi-Katarmal, Almora for provide antioxidant activity.

\section{Author Contribution}

The first author, Kavita Rawat persuade his Ph.D under the supervision of Prof Ganga Bisht carried out all the experiments work, Kundan Prasad the second author designed all the experiments and analyzed the data and prepared the manuscript. All authors read and approved the final manuscript.

\section{Conflicts of interest}

The authors declare that there is no conflict of interest.

\section{References}

1. Joshi RK. In vitro Antimicrobial Activity of the Essential Oil of Anaphalis contortaHook f. International Journal of Research in Pure and AppliedMicrobiology. 2011;1(2):19-21.
2. Polunin O, Stainton A. Flowers of the Himalaya. Oxford University Press. New Delhi. India, 1984. p. 187.

3. Gupta RK. Flora Nainitalensis. Navayug Traders, New Delhi, India, 1968. p. 185.

4. Wu YH. The vascular plants and eco-geographical distribution of the Qinghai-Tibetan Plateau. Science Press, Beijing, China, 2008. p. 947952.

5. Kirtiker KR, Basu BD. Indian Medicinal Plants. Indian Press, Allahabad, India, 1918. p. 681.

6. Saxena VK, Sahai A, Samaiya G. Studies on antimicrobial efficacy of essential oil of the leaves of Anaphalis contorta. Indian Perfumer, India. 1984;28:177-178.

7. Saxena VK, Sahai A, Jain AK. Gas Chromatography examination of the volatile constituents of the leaves of Anaphaliscontorta. Indian Perfumer, India. 1984;28:171-174.

8. European Pharmacopoeia. (3rd edn), Council of Europe, Strasbourg, France, 1996. p. 121-122.

9. Adams RP. Identification of Essential oil by Gas Chromatography Quadrupole Mass Spectrometry. Allured Publishing Corporation, Carol Stream, USA. 2001.

10. Bahukhandi A, Rawat S, Bhatt ID, et al. Influence of solvent types and source of collection on total phenolic content and antioxidant activities of Acorus calamus L. National Academy of Science Letters. 2013;36(1):93-99.

11. Bhatt ID, Dauthal P, Rawat S, et al. Characterization of essential oil composition, phenolic content, and antioxidant properties in wild and planted individuals of Valeriana jatamansiJones. Scientia Horticulturae. 2012;136:61-68.

12. Cai Y, Luo Q, Sun M, et al. Antioxidant activity and phenolic compounds of 112 traditional Chinese medicinal plants associated with anticancer. Life Sci. 2004;74(17):2157-2184.

13. Sanchez MC, Larrauri JA, Saura CF. Free radical scavenging capacity and inhibition of lipid oxidation of wines, grape juices and related polyphenolic constituents. Food Research International. 1994;32(6):407-412. 